\title{
Change of stand structure in upper tree line caused by disturbances
}

\author{
K. Gubka, J. Pittner
}

Technical university in Zvolen, Department of Silviculture, Faculty of Forestry, T. G. Masaryka 24, 96053 Zvolen, Slovak republic.E-mail:gubka@tuzvo.sk

\begin{abstract}
Gubka K., Pittner J. 2013: Change of stand structure in upper tree line caused by disturbances. - Beskydy, 6 (1): 75-86

In 2002, the series of 4 permanent research plots of different altitudes (difference $100 \mathrm{~m}$ ) was established in forest stand that is the part of upper tree line. In the plots we registered the quantitative and qualitative biometric characteristics of individual trees. The results showed that the stand is relatively statically stable (sufficient parameters of crown ratio and slenderness). The studied stand had adequate density and the number of stems was increasing with the decreasing altitude (from 1,460 to 1,260 $\mathrm{m}$ a.s.l.). The stand was comparable with the model one (yield tables) regarding the quantitative as well as qualitative parameters.

After the wind disturbance in 2004, two studied plots in higher altitudes were totally destroyed. In the time of repeated measurements (in 2010) the negative impact of the bark-beetle outbreak began to be visible. It was reflected in increased mortality of spruce also in the research plots situated in lower altitudes of studied stand. We confirmed that the neglect of forest hygiene and adequate silvicultural treatment leads to decline of stand condition and functionality in the upper tree line forests.
\end{abstract}

Keywords: upper tree line, Norway spruce, disturbance, wind, insects

\section{Introduction}

Mountain forests represent forest stands situated in high altitudes of mountains, they reach from $5^{\text {th }}$ to $7^{\text {th }}$ forest vegetation zone (Hladík et al. 1993), sometimes also the $8^{\text {th }}$ vegetation zone (mountain pine) is included. Based on the Report on Forestry in the Slovak Republic 2010, these represent nearly $34 \%$ of the total forest area of Slovakia. In the framework of these forests it is possible to point out the group of subalpine forests, meaning the forest stands that grow in the most extreme conditions and gradually penetrate the upper forest line. The definition of upper forest line is very diverse based on its source. Plesník (1971) defines it as a line that connects the highest situated points of the forest stand. Forest is here defined as a tree stand with the minimum canopy of 0.5 and minimum area of 10 ares, while tree is understood as an individual with the minimum height of 5 metres.
Based on the legislation (Forestry Law 326/2005 Z. z.) the subalpine forests are classified as a separate subcategory of protective forests. Their area is 49,500 hectares, which represents $2.6 \%$ of the forests of Slovak Republic. Despite the negligible percentage of these forests in Slovakia, their importance is considerably high due to their irreplaceable functions. Subalpine forests fulfil soil-protective, anti-erosion, anti-landslide, and anti-avalanche function. They play an important role in the water management and are used for relax, health, education and hunting. According to Hančinský (1972) this category typologically corresponds to the $7^{\text {th }}$ forest vegetation zone (unit 719 - subalpine spruce stands), or the small part to the $6^{\text {th }}$ forest vegetation zone (unit 618 - upper beechwoods). To sum this up, it is possible to say that the spruce forests are the main issue of the subalpine forest problems research in Slovakia. 
Nowadays the topic of upper forest line in Slovakia is a hot issue due to the sudden climatic changes, imissions and other factors that caused massive decline of subalpine forests and so the upper forest line as well (Kucbel, Vencúrik 2008).

The main goal of this paper was to analyze the change of stand structure in the area of upper tree line caused by wind disturbance. A secondary goal was to show the possible negatives caused by neglect of the silvicultural treatment and forest hygiene, which has a decline effect on their condition.

\section{Material and methods}

\section{Site description}

Forest tenure unit (FTU) of the state forests of Tatra National Park (SF TANAP) is situated in four forest zones: 43 Podtatranská kotlina; 47 Tatry; 46 Nízke Tatry Kozie chrbty; 42 Levočské vrchy).

Geological constitution of the area is considerably differentiated and based on these building elements: crystalline core; base paleogen and flysch; dark limestones, dolomites).

The dominant part is situated in the cold area. On the territory of FTU could be seen three types of annual precipitation cycle: 1. Basin type: in the altitudes under $900 \mathrm{~m}$ and with the average amplitude of precipitation between most dry and most wet month over $90 \mathrm{~mm}$; 2. Valley-hillside type: altitude $900-2000 \mathrm{~m}$, with the precipitation over $900 \mathrm{~mm}$ and amplitude over $90 \mathrm{~mm}$; 3. Alpine type: altitude over $2,000 \mathrm{~m}$

On the territory of FTU is dominant soil nutrient regime type A - acid (70\% of the area) and in the soil there is dominance of ranker soils and podsols.

On the area of FTU the $6^{\text {th }}$ forest vegetation zone (FVZ) (spruce-beech-fir) is most present, and takes $35 \%$ of the territory. Second is the $7^{\text {th }}$ FVZ (spruce), which is on $28 \%$ of the area. Next is the $8^{\text {th }} \mathrm{FVZ}$ (mountain pine), which covers $28 \%$ and the $5^{\text {th }}$ FVZ (fir-beech) $15 \%$ of the territory.

In this particular territory is dominant spruce up to the upper forest line where is locally penetrated by Swiss pine. In the indigenous tree species composition beech was present as well and the dominance of spruce was not that strong.

The research site is situated in the FTU SF TANAP, which is divided into 12 protective districts. Observed forest cover is situated in the Protective district Podspády.

Permanent research plots (PRP) PRP I-PRP IV were established in 2002 in the stand 1764, and in 2010 actual state of forest stand was registered again. PRP I-PRP IV were in the stand situated gradually every $100 \mathrm{~m}$ of the altitude. Every PRP has the size of $0.25 \mathrm{ha}(50 \times 50 \mathrm{~m})$. A transect was set in every PRP in the direction of the slope and in the size $10 \times 50 \mathrm{~m}$ ( 5 ares). Every PRP has been stabilized in the terrain in its corners and among its lines with the wooden pegs. The trees neighbouring the PRP areas were marked with a white colour horizontal stripe in the height 1.3-1.5 meters. The mean altitude of PRPs was: PRP I - 1,460 m; PRP II - 1,360 m; PRP III 1,260 m; PRP IV - 1,160 m.

The characteristics of the stand by Forest management plan: Stand number: 1746; Area: 18.10 ha; Total growing stock: $8,923 \mathrm{~m}^{3}$; Crop density: 0.7; Age: 130 years; Tree species composition: Norway spruce - $100 \%$, rarely sycamore maple; Average height: 29.0 m; Average diameter: $38.0 \mathrm{~m}$; Volume of the mean stem: $1.32 \mathrm{~m}^{3}$; Site index: 26; Aspect: NW; Slope: 70\%; Soil: rocky, crags in the south; Regeneration period: continuous; Regeneration composition: Norway spruce $70 \%$, silver fir $20 \%$, sycamore maple $10 \%$.

State of the forest in 2002: stand is composed of thick stemwood, very age-differentiated, irregularly developed and sporadically sparse. On the SE in some places windthrows, medium endangered stand. Between the years 1997-2000 there was processed logging in the volume of $344 \mathrm{~m}^{3}$. There is an occurrence of dying individuals, sporadically trunk and tree crown breakage.

State of the forest in 2010: the forest cover is considerably destroyed due to the effect of wind calamity in 2004 and subsequent outbreak of bark beetle as a secondary harmful element. The forest stand on PRP I and PRP II has perished. The stand on the PRP III and IV is damaged to considerable extent.

\section{Methods of measurement}

On every PRP we recorded qualitative and quantitative characteristics that were object of further evaluation. The individuals were categorized into two basic groups: 1. Living trees; 2. Standing dead trees.

On the PRP's in the case of living trees were researched and measured following characteristics: Diameter at the breast height (DBH) with the accuracy to $1 \mathrm{~mm}$; Tree height the accuracy to $0.5 \mathrm{~m}$; Crown base height with the accuracy to $0.5 \mathrm{~m}$; Tree class according to Polanský (in Saniga 2007): 1. Predominant, 2. Dominant, 3. Codominant, 4. Suppressed; The quality of the tree crown of the individuals - categorized into 3 degrees: 1. Symmetric tree crown with the 
length $2 / 3$ to $1 \frac{1}{2}$ of the tree height with good vitality, 2 . Slightly asymmetric crow with the length under $2 / 3$ to $1 / 2$ tree height and average vitality, 3 . Very asymmetric and short tree crown with insufficient vitality

The same characteristics, except of the tree crown quality, were registered in dead standing trees as well.

On the transect of each PRP was observed the state of the natural regeneration and the individuals were put in the height groups according to the tree species: individuals up to $20 \mathrm{~cm}$, differentiated by age ( $1,2,3,4,5+$ year old); individuals from 21 to $50 \mathrm{~cm}$; individuals from 51 to $80 \mathrm{~cm}$; individuals from 81 to $130 \mathrm{~cm}$; individuals over $130 \mathrm{~cm}$ up to the diameter $d_{1,3}=20 \mathrm{~cm}$.

Acquired information were evaluated and tested with the software STATISTICA 8.0. The differences of diameter values between monitored PRPs were tested by the nonparametric analysis of variance of Kruskall-Wallis and the influence of the altitude on the dead standing trees occurrence was tested by $\chi^{2}$-test.

\section{Results and evaluation}

The functionality of forest stands is determined by the complex of factors among which the stand density is one of the most important one.

The stand 1764 in the locality Medzisteny has the amplitude of altitude from $1,110 \mathrm{~m}$ (S) up to $1,520 \mathrm{~m}(\mathrm{~N})$. The analysis of stem density (trees with dbh more than $2 \mathrm{~cm}$ ) in the time of the beginning of the research (2002) showed very differentiated occurrence of the trees in the particular altitudes (observed PRP). In the framework of this extent we found out in 2002 a different frequency of the individuals on the observed PRP (in different altitudes) (Tab. 1).

On the highest situated research plot (PRP I, $1,460 \mathrm{~m}$ ) were discovered 256 standing tree individuals of the spruce on 1 ha at the beginning of the research (2002), of which 204 were living (79.7\%) and 52 dead standing (20.3\%). With the decreasing altitude the rising number of the standing trees was observed. In the altitude 1,360 m (PRP II) 372 individuals were found and in the altitude $1,260 \mathrm{~m}$ (PRP III) up to 412 pcs. $\mathrm{ha}^{-1}$. The proportion of the living trees was $77.4 \%$ (PRP II) up to 85.4\% (PRP III) (Tab. 1).

The decrease of the numbers of individuals was interesting on PRP IV (1,160 m) where we discovered only 288 standing trees, out of which 256 (88.9\%) were living. The number of living trees was higher than that on PRP I and comparable to PRP II. The absolute as well as relative numbers of dead trees were considerably lower on PRP IV than on the other research plots (Tab. 1).

To assess the influence of the altitude on the occurrence of dead standing trees we used $\chi^{2}$ test, with the level of importance $\alpha=0.05$ and 3 degrees of freedom $(r)[r=(4-1) *(2-1)=3]$. The table value was $\chi_{0.05(3)}^{2}=7.815$. We counted the value $18.763>7.815$ what points out the significant influence of altitude on the occurrence of dead trees, on the level of $95 \%$ of importance. For the more accurate information the degree of influence 1 (coefficient of contingency) was calculated. The calculated coefficient $\mathrm{c}=0.12$ point out the small degree of dependence. This was approved by the test of the hypotheses of the proportion of qualitative characteristic (dead tree). As the relative abundance (w) of the observed characteristics (dead tree) was lower than $30 \%$ ( $\mathrm{w}<0.3$ ), there was used $\varphi$ (Tab. VII, Šmelko (1991)). Based on the calculated value " $\mathrm{z}$ ", that was in the comparisons of PRP IV with the plots I and III higher than in the tables $\left(\mathrm{z}_{0.05}=1.645\right)$. It was possible to asset that the difference of the dead trees on observed areas was statistically important on $95 \%$ of the importance level. The reason was apparently the complex of stressing factors, which were present in the studied locality. There was not found any important difference between PRP IV and III. One of the reasons is as well sanitary logging in the lower part of forest stand (ca. up to PRP IV), which is accessible from the forest road.

Based on the evidence of stem density we have found out that in the time of establishment of research plots (year 2002), the vertical structure on all plots was little height differentiated. In the $1^{\text {st }}$ and $2^{\text {nd }}$ tree class was found out $77.8 \%$ (PRP II) up to $93.8 \%$ (PRP IV) of living trees. The higher vertical differentiation was discovered on higher settled PRP (I and II) than on the lower situated plots (Tab. 1).

Relatively high portion of dead individuals of lower tree classes on the research plots II, III, IV points out to the negative influence of a long-term shading on their living conditions. On PRP I, where was observed the tendency of open canopy horizontal structure, where the individuals were concentrated in the clusters, respectively smaller groups, the emergence of dead individuals in the lower tree classes was minimal. Due to the extreme climate conditions as well as due to pollution, there was higher number of dead trees in the $1^{\text {st }}$ and $2^{\text {nd }}$ tree class (Tab. 1).

The diameter distributions point out to the fact, that with the increasing altitude the 
Tab. 1: Stem density of spruce standing trees in the time according the tree classes (stand 1764, locality Medzisteny) (calculation perhectare).

\begin{tabular}{|c|c|c|c|c|c|c|c|c|c|c|c|c|c|}
\hline \multirow{3}{*}{ PRP } & \multirow{3}{*}{$\begin{array}{l}\text { Tree } \\
\text { class }\end{array}$} & \multicolumn{6}{|c|}{ Year 2002} & \multicolumn{6}{|c|}{ Year 2010} \\
\hline & & \multicolumn{2}{|c|}{ Live } & \multicolumn{2}{|c|}{ Dead } & \multicolumn{2}{|c|}{ Total } & \multicolumn{2}{|c|}{ Live } & \multicolumn{2}{|c|}{ Dead } & \multicolumn{2}{|c|}{ Total } \\
\hline & & $\mathbf{N}$ & $\%$ & $\mathbf{N}$ & $\%$ & $\mathbf{N}$ & $\%$ & $\mathbf{N}$ & $\%$ & $\mathbf{N}$ & $\%$ & $\mathbf{N}$ & $\%$ \\
\hline & 1 & 60 & 29.4 & 28 & 53.8 & 88 & 34.4 & & & & & & \\
\hline I. & 2 & 100 & 49.0 & 16 & 30.8 & 116 & 45.3 & & & & & & \\
\hline Altitude & 3 & 20 & 9.8 & 4 & 7.7 & 24 & 9.4 & & & & & & \\
\hline \multirow[t]{4}{*}{$1460 \mathrm{~m}$} & 4 & 24 & 11.8 & 4 & 7.7 & 28 & 10.9 & & & & & & \\
\hline & Total & 204 & 100.0 & 52 & 100.0 & 256 & 100.0 & & & & & & \\
\hline & $\%$ & \multicolumn{2}{|c|}{79.7} & \multicolumn{2}{|c|}{20.3} & \multicolumn{2}{|c|}{100.0} & & & & & & \\
\hline & 1 & 84 & 29.2 & 4 & 4.8 & 88 & 23.7 & & & & & & \\
\hline II. & 2 & 140 & 48.6 & 0 & 0.0 & 140 & 37.6 & & & & & & \\
\hline Altitude & 3 & 20 & 6.9 & 20 & 23.8 & 40 & 10.8 & & & & & & \\
\hline \multirow[t]{4}{*}{$1360 \mathrm{~m}$} & 4 & 44 & 15.3 & 60 & 71.4 & 104 & 28.0 & & & & & & \\
\hline & Total & 288 & 100.0 & 84 & 100.0 & 372 & 100.0 & & & & & & \\
\hline & $\%$ & \multicolumn{2}{|c|}{77.4} & \multicolumn{2}{|c|}{22.6} & \multicolumn{2}{|c|}{100.0} & & & & & & \\
\hline & 1 & 124 & 35.2 & 0 & 0.0 & 124 & 30.1 & 72 & 26.9 & 4 & 4.0 & 76 & 20.7 \\
\hline III. & 2 & 192 & 54.5 & 8 & 13.3 & 200 & 48.5 & 108 & 40.3 & 40 & 40.0 & 148 & 40.2 \\
\hline Altitude & 3 & 32 & 9.1 & 16 & 26.7 & 48 & 11.7 & 72 & 26.9 & 16 & 16.0 & 88 & 23.9 \\
\hline \multirow[t]{4}{*}{$1260 \mathrm{~m}$} & 4 & 4 & 1.1 & 36 & 60.0 & 40 & 9.7 & 16 & 6.0 & 40 & 40.0 & 56 & 15.2 \\
\hline & Total & 352 & 100.0 & 60 & 100.0 & 412 & 100.0 & 268 & 100.0 & 100 & 100.0 & 368 & 100.0 \\
\hline & $\%$ & \multicolumn{2}{|c|}{85.4} & \multicolumn{2}{|c|}{14.6} & \multicolumn{2}{|c|}{100.0} & \multicolumn{2}{|c|}{72.8} & \multicolumn{2}{|c|}{27.2} & \multicolumn{2}{|c|}{100.0} \\
\hline & 1 & 76 & 29.7 & 4 & 12.5 & 80 & 27.8 & 4 & 10.0 & 12 & 23.1 & 16 & 17.4 \\
\hline IV. & 2 & 164 & 64.1 & 0 & 0.0 & 164 & 56.9 & 32 & 80.0 & 16 & 30.8 & 48 & 52.2 \\
\hline Altitude & 3 & 16 & 6.3 & 4 & 12.5 & 20 & 6.9 & 4 & 10.0 & 20 & 38.5 & 24 & 26.1 \\
\hline \multirow[t]{5}{*}{$1160 \mathrm{~m}$} & 4 & 0 & 0.0 & 24 & 75.0 & 24 & 8.3 & 0 & 0.0 & 4 & 7.7 & 4 & 4.3 \\
\hline & Total & 256 & 100.0 & 32 & 100.0 & 288 & 100.0 & 40 & 100.0 & 52 & 100.0 & 92 & 100.0 \\
\hline & $\%$ & & 3.9 & & 1.1 & & 0.0 & & & & .5 & & 0.0 \\
\hline & 1 & 86 & 31.3 & 9 & 15.8 & 95 & 28.6 & 38 & 24.7 & 8 & 10.5 & 46 & 20.0 \\
\hline & 2 & 149 & 54.2 & 6 & 10.5 & 155 & 46.7 & 70 & 45.5 & 28 & 36.8 & 98 & 42.6 \\
\hline Average & 3 & 22 & 8.0 & 11 & 19.3 & 33 & 9.9 & 38 & 24.7 & 18 & 23.7 & 56 & 24.3 \\
\hline & 4 & 18 & 6.5 & 31 & 54.4 & 49 & 14.8 & 8 & 5.2 & 22 & 28.9 & 30 & 13.0 \\
\hline & Total & 275 & 100.0 & 57 & 100.0 & 332 & 100.0 & 154 & 100.0 & 76 & 100.0 & 230 & 100.0 \\
\hline & $\%$ & & .8 & & 7.2 & & 0.0 & & & & .0 & & 0.0 \\
\hline
\end{tabular}

polygon of abundance distribution is moving to the right. The most represented diameter classes with growing altitudes were moving more to the thicker dimensions. Interesting was as well the decline of the number of the individuals in the diameter classes 38-42-46 cm (Fig. 1). This was probably caused by the disturbances in the previous period, when the individuals of exact diameter were the least resistant to the negative effect.
The shift of the diameter distributions to the right with the decreasing altitude became evident on the average values of biometric characteristics.

The lowest average values of diameter and height were discovered on the highest situated site (PRP I, 1,460 m). The average diameter was up to $39.0 \pm 15.5 \mathrm{~cm}$ and height $19.5 \pm 7.0 \mathrm{~m}$. (Tab. 2). A different situation was on the PRP IV, where the average diameter values were 


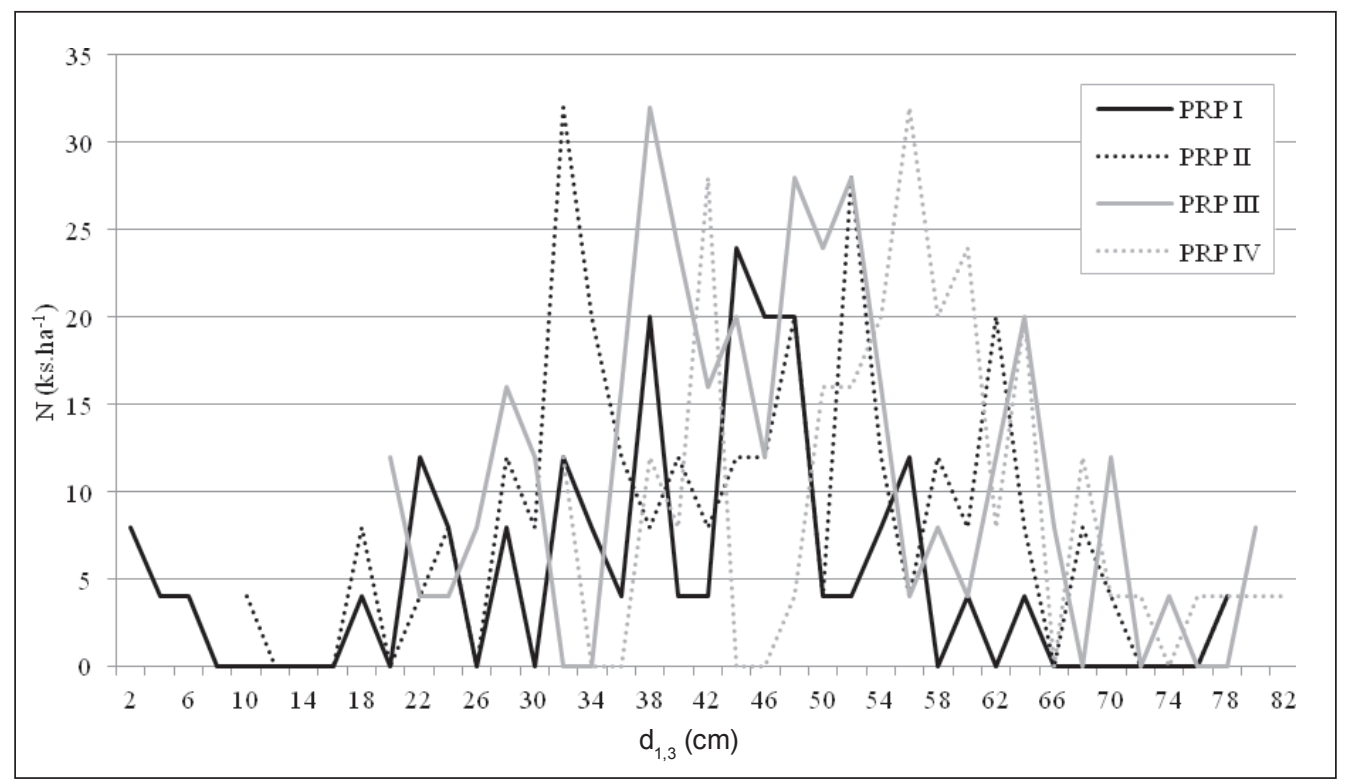

Fig. 1: The diameter distributions of spruce based on the diameter classes on researched PRP I-IV in the stand 1764 in the locality Medzisteny.

$54.9 \pm 11.4 \mathrm{~cm}$ and average heights $28.1 \pm 6.5 \mathrm{~m}$ (Tab. 2).

The nonparametric analysis of variance by Kruskall-Wallis points out the statistically important differences in the diameter average values on particular research plots, except of PRP II and PRP III in 2002 (Tab. 3). The increase of the diameter with decreasing altitude is evident as well on the Fig. 2.

The differentiation of stem density, diameter and height is visible as well in the stand volume on particular PRPs, or rather in different altitudes.

In 2002 the smallest stand volume was discovered on the highest research site (PRP I). Out of the discovered $331.1 \mathrm{~m}^{3}$.ha ${ }^{-1}$ was up to $19.5 \%$ dead $\left(64.6 \mathrm{~m}^{3} \cdot \mathrm{ha}^{-1}\right)$. Such a high share of the stand volume was the consequence of tree decay in the $1^{\text {st }}$ and $2^{\text {nd }}$ tree class. On the lower situated PRPs was the stand volume of standing trees much higher, and the share of dead individuals in the stand volume was from $2.4 \%$ to $6.1 \%$. The highest stand volume of living trees $\left(823.4 \mathrm{~m}^{3} . \mathrm{ha}^{-}\right.$ 1) was on PRP III in the altitude 1,260 m (Tab. 4).

One of the basic conditions of functionality of forest ecosystems is the biological suitability and static stability of particular forest components. The dominance of spruce on these sites emerges from the ecological needs of the spruce and ecological conditions of the site. This is approved as well by the phytocoenological research, which found out that $90 \%$ of the stand area is covered by the forest type 7405 - limestone maple-spruce forests.

Static stability is relatively well characterized by the slenderness ratio and the size of the crowns (crown ratio).

Based on the results from 2002 we see, that based on the values of slenderness ratio and the size of the crowns, the stand could be considered as relatively stable. The average values of slenderness ratio ranged from $50 \pm 18$ on PRP I to $56 \pm 12$ on PRP III (Tab. 2). The average size of the crown was from $15.2 \pm 5.9 \mathrm{~m}$ (PRP I) to $19.1 \pm 5.7 \mathrm{~m}$ (PRP IV), which in relative values represents $66.7-78.1 \%$ of the tree height (crown ratio) (Tab. 2).

Static stability of the trees in the relation to abiotic factors is very influenced by the shape and quality of the crown. In the time of research plots establishment we found out, that the quality of the spruce tree crowns increased with the decreasing altitude. In the altitude $1,360 \mathrm{~m}$ the average stand quality on the observed PRPs was on the level 2.3 of quality degree. $200 \mathrm{~m}$ lower in altitude (PRP IV) was discovered average value 1.4 degree that is in comparison with PRP II improvement by 0.9 quality degree (Tab. 5).

Regardless of the altitude, the best quality of tree crowns was on the studied plots in the $1^{\text {st }}$ tree class. In the lower tree classes, the quality of tree crown was decreasing and in the $2^{\text {nd }}$ tree class on PRP IV was comparable with $1^{\text {st }}$ tree class (1.4 degree) (Tab. 5). Considerable 
Tab.2: The basic statistical characteristics of the observed biometric signs on PRP I-IV in 2002 (stand 1764, locality Medzisteny).

\begin{tabular}{|c|c|c|c|c|c|c|c|}
\hline \multicolumn{2}{|l|}{ Year } & \multicolumn{4}{|c|}{2002} & \multicolumn{2}{|c|}{2010} \\
\hline \multirow{2}{*}{$\begin{array}{l}\text { Biometrical } \\
\text { sign }\end{array}$} & \multirow{2}{*}{$\begin{array}{l}\text { Statistical } \\
\text { charact. }\end{array}$} & PRP I & PRP II & PRP III & PRP IV & PRP III & PRP IV \\
\hline & & $\begin{array}{c}1460 \\
\text { m a.s.l. }\end{array}$ & $\begin{array}{c}1360 \\
\text { m a.s.l. }\end{array}$ & $\begin{array}{c}1260 \\
\text { m a.s.l. }\end{array}$ & $\begin{array}{c}1160 \\
\text { m a.s.l. }\end{array}$ & $\begin{array}{c}1260 \\
\text { ma.s.l. }\end{array}$ & $\begin{array}{c}1160 \\
\text { ma.s.l. }\end{array}$ \\
\hline \multirow{3}{*}{ DBH (cm) } & $\overline{\mathrm{x}}$ & 39.0 & 44.3 & 46.6 & 54.9 & 50.8 & 54.2 \\
\hline & $S x( \pm)$ & 15.5 & 14.1 & 13.7 & 11.4 & 12.8 & 13.4 \\
\hline & $\mathrm{Vx}(\%)$ & 39.7 & 31.8 & 29.4 & 20.8 & 25.2 & 24.7 \\
\hline \multirow{3}{*}{ Height (m) } & $\bar{x}$ & 19.5 & 22.4 & 26.1 & 28.1 & 30.4 & \\
\hline & $S x( \pm)$ & 7.0 & 7.5 & 8.1 & 6.5 & 4.8 & \\
\hline & $\mathrm{Vx}(\%)$ & 35.9 & 33.5 & 31.0 & 23.1 & 15.8 & \\
\hline \multirow{3}{*}{ Crown base (m) } & $\overline{\mathrm{x}}$ & 6.5 & 8.2 & 10.9 & 11.0 & 9 & \\
\hline & $S x( \pm)$ & 4.0 & 3.9 & 5.3 & 3.9 & 3.7 & \\
\hline & $\mathrm{Vx}(\%)$ & 61.5 & 47.6 & 48.6 & 35.5 & 41.1 & \\
\hline \multirow{3}{*}{$\begin{array}{c}\text { Crown length } \\
(\mathrm{m})\end{array}$} & $\bar{x}$ & 15.2 & 17.9 & 17.4 & 19.1 & 21.4 & \\
\hline & $S x( \pm)$ & 5.9 & 6.7 & 6.2 & 5.7 & 6.9 & \\
\hline & $\mathrm{Vx}(\%)$ & 38.8 & 37.4 & 35.6 & 29.8 & 32.2 & \\
\hline Crown ratio & $\%$ & 78.1 & 80.0 & 66.7 & 67.8 & 69 & \\
\hline \multirow{3}{*}{$\begin{array}{l}\text { Slenderness } \\
\text { ratio }\end{array}$} & $\overline{\mathrm{x}}$ & 50.0 & 50.6 & 56.0 & 51.2 & 62.5 & \\
\hline & $S x( \pm)$ & 18.4 & 18.3 & 12.0 & 9.9 & 11.2 & \\
\hline & $\mathrm{Vx}(\%)$ & 36.8 & 36.2 & 21.4 & 19.3 & 17.9 & \\
\hline \multirow{4}{*}{ Middle stem } & $\mathrm{d}_{1,3}(\mathrm{~cm})$ & 43.7 & 45.9 & 50.1 & 56.6 & 60.0 & 56.6 \\
\hline & $\mathrm{h}(\mathrm{m})$ & 26.3 & 27.0 & 30.6 & 30.8 & 32.5 & \\
\hline & $\mathrm{V}\left(\mathrm{m}^{3}\right)$ & 1.31 & 1.97 & 2.34 & 3.05 & 2.77 & 3.01 \\
\hline & $\mathrm{G}\left(\mathrm{m}^{2}\right)$ & 0.14 & 0.17 & 0.19 & 0.25 & 0.22 & 0.24 \\
\hline \multirow{3}{*}{ Crop density } & $\mathrm{N}$ & 0.42 & 0.59 & 0.72 & 0.52 & 0.54 & 0.11 \\
\hline & $\mathrm{V}$ & 0.33 & 0.71 & 1.02 & 0.97 & 0.80 & 0.17 \\
\hline & G & 0.48 & 0.84 & 1.10 & 1.07 & 0.87 & 0.19 \\
\hline Canopy closure & $\%$ & 0.23 & 0.59 & 0.65 & 0.44 & & \\
\hline
\end{tabular}

Tab. 3: The nonparametric analysis of variance of diameter values by Kruskall-Wallis in 2002 (stand 1764, locality Medzisteny).

\begin{tabular}{lllll}
\hline & \multicolumn{1}{c}{ PRP I } & \multicolumn{1}{c}{ PRP II } & PRP III & PRP IV \\
\hline PRP I & & $0.0075^{* *}$ & $0.0000^{* * *}$ & $0.0000^{* * *}$ \\
PRP II & $0.0075^{* *}$ & & 0.4427 & $0.0000^{* * *}$ \\
PRP III & $0.0000^{* * *}$ & 0.4427 & & $0.0000^{* * *}$ \\
PRP IV & $0.0000^{* * *}$ & $0.0000^{* * *}$ & $0.0000^{* * *}$ & \\
\hline
\end{tabular}




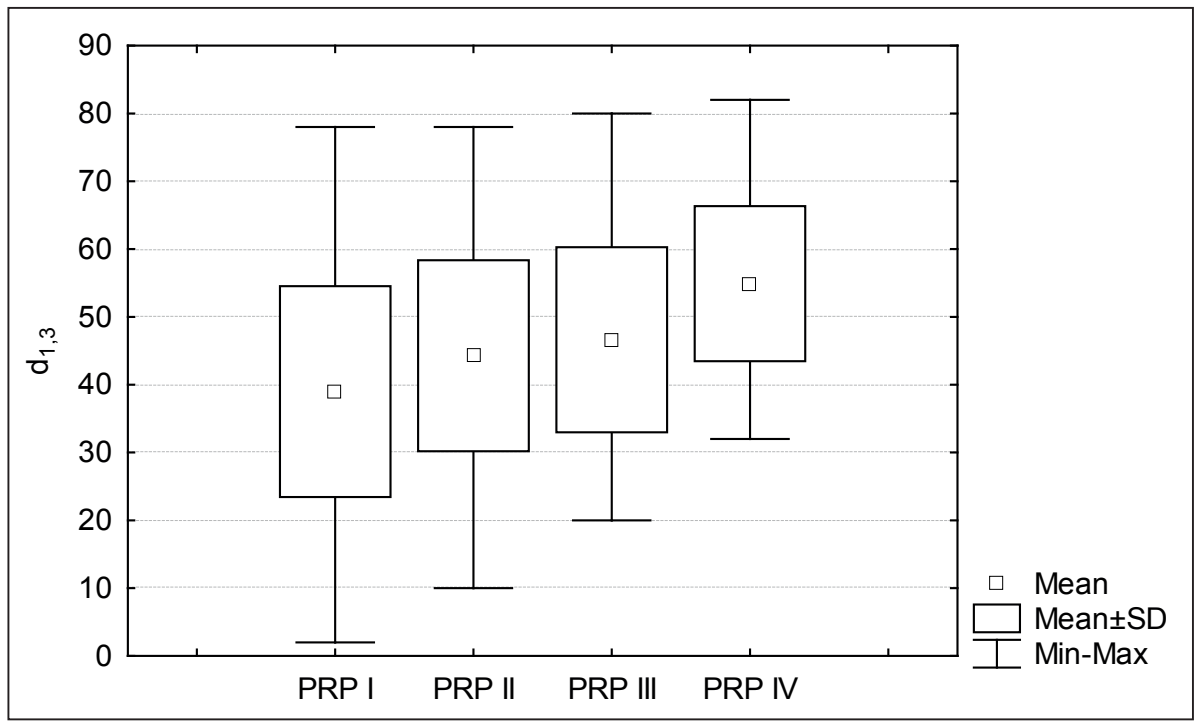

Fig. 2: Difference of the diameter values with regard on the altitude change in 2002 (stand 1764, locality Medzisteny).

Tab. 4: Stand volume of the observed PRP in 2002 and 2010 (stand 1764, locality Medzisteny)(calculation perhectare).

\begin{tabular}{|c|c|c|c|c|c|c|c|c|c|c|}
\hline \multirow{3}{*}{$\begin{array}{l}\text { Year } \\
\text { PRP }\end{array}$} & \multicolumn{5}{|c|}{2002} & \multicolumn{5}{|c|}{2010} \\
\hline & \multicolumn{2}{|c|}{ Live } & \multicolumn{2}{|c|}{ Dead } & \multirow{2}{*}{$\frac{\text { Total }}{100 \%}$} & \multicolumn{2}{|c|}{ Live } & \multicolumn{2}{|c|}{ Dead } & \multirow{2}{*}{$\frac{\text { Tota }}{100 \%}$} \\
\hline & $\mathrm{m}^{3}$ & $\%$ & $\mathrm{~m}^{3}$ & $\%$ & & $\mathrm{~m}^{3}$ & $\%$ & $\mathrm{~m}^{3}$ & $\%$ & \\
\hline I. & 266.5 & 80.5 & 64.6 & 19.5 & 331.1 & & & & & \\
\hline II. & 567.6 & 93.9 & 36.6 & 6.1 & 604.2 & & & & & \\
\hline III. & 823.4 & 96.6 & 28.7 & 3.4 & 852.1 & 676.4 & 78.1 & 190.0 & 21.9 & 866.4 \\
\hline IV. & 779.7 & 97.6 & 19.4 & 2.4 & 799.1 & 144.5 & 19.6 & 591.8 & 80.4 & 736.3 \\
\hline
\end{tabular}

improvement of tree crown quality in the $4^{\text {th }}$ tree class on PRP I was clearly due to the better light conditions, as the forest stand on this plot (in this altitude) had a tendency to create cluster or group horizontal structure. The other forms of the low quality of crowns and trunks (twin-stem, fork-stem, broken crown, mechanical damage of trunks) appeared only sporadically in the range from $1.4 \%$ (PRP IV) up to 9.4\% (PRP I).

The natural regeneration in 2002 was on the very low level. On the highest situated plot (PRP I) were registered 2,540 pcs.ha ${ }^{-1}$ out of which only 360 individuals (14.2\%) were higher than $20 \mathrm{~cm}$. The spruce here was represented only by 20 pieces (Tab. 6).

On the lower situated PRP the situation with the occurrence of individuals higher than $20 \mathrm{~cm}$ and more was even worse. For example on PRP II, out of 5,180 pcs.ha-1 only 200 pieces of rowan were higher than $20 \mathrm{~cm}$. On PRP III and IV there were no individuals above $20 \mathrm{~cm}$.
The number of standing trees on PRP III decreased in 2010 to 368 pcs.ha-1 ${ }^{-1}$ out of which 268 individuals (72.8\%) were alive. The share of the dead standing trees on 1 ha was 100 pcs (27.2\%). The results of wind calamity appeared on this plot in considerable change of the distribution of spruce in the vertical structure. Emerging from the Table 1, there was a considerable increase of the tree numbers in the $3^{\text {rd }}$ tree class (codominant). The cause is in the high number of individuals with the crown breakings, which cause the shift to the lower tree classes. Out of 268 living standing trees, the crown breakings appeared in 88 individuals (23.9\%) calculated pre hectare. In the $2^{\text {nd }}$ tree class there were 24 pieces, in the $3^{\text {rd }} 52$ pcs and in the $4^{\text {th }} 12$ pcs.

The decrease of the number of the standing trees was even higher on PRP IV. In 2010, only 92 standing spruce trees per hectare were discovered on this plot, out of which up to 52 were dead (56.5\%) (Tab.1). The decrease of the individuals was partially caused by the wind 
Tab. 5: Abundance analysis of living spruces according to crown quality and tree class in stand 1764, locality Medzisteny (calculation perhectare).

\begin{tabular}{|c|c|c|c|c|c|c|c|c|c|c|c|}
\hline \multicolumn{12}{|c|}{ Year 2002} \\
\hline \multirow{2}{*}{ PRP } & \multirow{2}{*}{$\begin{array}{l}\text { Crown } \\
\text { quality }\end{array}$} & \multicolumn{2}{|c|}{ Tree class 1} & \multicolumn{2}{|c|}{ Tree class 2} & \multicolumn{2}{|c|}{ Tree class 3} & \multicolumn{2}{|c|}{ Tree class 4} & \multicolumn{2}{|c|}{ Total } \\
\hline & & $\mathbf{N}$ & \% Total & $\mathbf{N}$ & \% Total & $\mathbf{N}$ & \% Total & $\mathbf{N}$ & \% Total & $\mathbf{N}$ & $\%$ \\
\hline \multirow{5}{*}{ I. } & 1 & 8 & 3.9 & 0 & 0.0 & 0 & 0.0 & 12 & 5.9 & 20 & 9.8 \\
\hline & 2 & 48 & 23.5 & 64 & 31.4 & 4 & 2.0 & 4 & 2.0 & 120 & 58.8 \\
\hline & 3 & 4 & 2.0 & 36 & 17.6 & 16 & 7.8 & 8 & 3.9 & 64 & 31.4 \\
\hline & Total & 60 & 29.4 & 100 & 49.0 & 20 & 9.8 & 24 & 11.8 & 204 & 100.0 \\
\hline & $\bar{x}$ & \multicolumn{2}{|r|}{1.9} & \multicolumn{2}{|r|}{2.4} & \multicolumn{2}{|r|}{2.8} & \multicolumn{2}{|r|}{1.8} & \multicolumn{2}{|c|}{2.2} \\
\hline \multirow{5}{*}{ II. } & 1 & 24 & 8.3 & 4 & 1.4 & 0 & 0.0 & 0 & 0.0 & 28 & 9.7 \\
\hline & 2 & 56 & 19.4 & 80 & 27.8 & 0 & 0.0 & 12 & 4.2 & 148 & 51.4 \\
\hline & 3 & 4 & 1.4 & 56 & 19.4 & 20 & 6.9 & 32 & 11.1 & 112 & 38.9 \\
\hline & Total & 84 & 29.2 & 140 & 48.6 & 20 & 6.9 & 44 & 15.3 & 288 & 100.0 \\
\hline & $\bar{x}$ & \multicolumn{2}{|r|}{1.8} & \multicolumn{2}{|r|}{2.4} & \multicolumn{2}{|r|}{3.0} & \multicolumn{2}{|r|}{2.7} & \multicolumn{2}{|c|}{2.3} \\
\hline \multirow{5}{*}{ III. } & 1 & 80 & 22.7 & 64 & 18.2 & 4 & 1.1 & 0 & 0.0 & 148 & 42.0 \\
\hline & 2 & 36 & 10.2 & 96 & 27.3 & 12 & 3.4 & 0 & 0.0 & 144 & 40.9 \\
\hline & 3 & 8 & 2.3 & 32 & 9.1 & 16 & 4.5 & 4 & 1.1 & 60 & 17.0 \\
\hline & Total & 124 & 35.2 & 192 & 54.5 & 32 & 9.1 & 4 & 1.1 & 352 & 100.0 \\
\hline & $\bar{x}$ & \multicolumn{2}{|r|}{1.4} & \multicolumn{2}{|r|}{1.8} & \multicolumn{2}{|r|}{2.4} & \multicolumn{2}{|r|}{3.0} & \multicolumn{2}{|c|}{1.8} \\
\hline & 1 & 44 & 17.2 & 112 & 43.8 & 4 & 1.6 & 0 & 0.0 & 160 & 62.5 \\
\hline & 2 & 32 & 12.5 & 44 & 17.2 & 12 & 4.7 & 0 & 0.0 & 88 & 34.4 \\
\hline IV. & 3 & 0 & 0.0 & 8 & 3.1 & 0 & 0.0 & 0 & 0.0 & 8 & 3.1 \\
\hline & Total & 76 & 29.7 & 164 & 64.1 & 16 & 6.3 & 0 & 0.0 & 256 & 100.0 \\
\hline & $\bar{x}$ & & 1.4 & & 1.4 & & 1.8 & & 0.0 & & 4 \\
\hline & & & & & Year & 10 & & & & & \\
\hline & 1 & 0 & 0.0 & 4 & 1.5 & 0 & 0.0 & 0 & 0.0 & 4 & 1.5 \\
\hline & 2 & 44 & 16.4 & 56 & 20.9 & 8 & 3.0 & 0 & 0.0 & 108 & 40.3 \\
\hline III. & 3 & 28 & 10.4 & 48 & 17.9 & 64 & 23.9 & 16 & 6.0 & 156 & 58.2 \\
\hline & Total & 72 & 26.9 & 108 & 40.3 & 72 & 26.9 & 16 & 6.0 & 268 & 100.0 \\
\hline & $\bar{x}$ & & 2.4 & & 2.4 & & 2.9 & & 3.0 & & 6 \\
\hline & 1 & 4 & 10.0 & 0 & 0.0 & 0 & 0.0 & 0 & 0.0 & 4 & 10.0 \\
\hline & 2 & 0 & 0.0 & 32 & 80.0 & 0 & 0.0 & 0 & 0.0 & 32 & 80.0 \\
\hline IV. & 3 & 0 & 0.0 & 0 & 0.0 & 4 & 10.0 & 0 & 0.0 & 4 & 10.0 \\
\hline & Total & 4 & 10.0 & 32 & 80.0 & 4 & 10.0 & 0 & 0.0 & 40 & 100.0 \\
\hline & $\overline{\mathrm{x}}$ & & 1.0 & & 2.0 & & 3.0 & & 0.0 & & 0 \\
\hline
\end{tabular}

disturbance. The high share of dead standing trees was in this plot caused by the spontaneous appearance of bark-beetles, particularly of Ips typographus and Pityogenes chalcographus. The analysis of vertical and horizontal structure, as well as of diameter distributions seems to us as meaningless. Majority of the living trees was in the diameter classes $40-44 \mathrm{~cm}$ and $56-60 \mathrm{~cm}$ $\left(\right.$ per 16 pcs.ha $^{-1}$ ).
In 2010, the best preserved research plot was PRP III. The stand volume on this plot was according to calculations on hectare $866.4 \mathrm{~m}^{3}$, out of which $676.4 \mathrm{~m}^{3}$ (78.1\%) were living trees (Tab. 4). The increase of stand volume during the time of the research shows the preservation of the reproduction ability even after the wind calamity, which uprooted considerable part of the forest stand. 


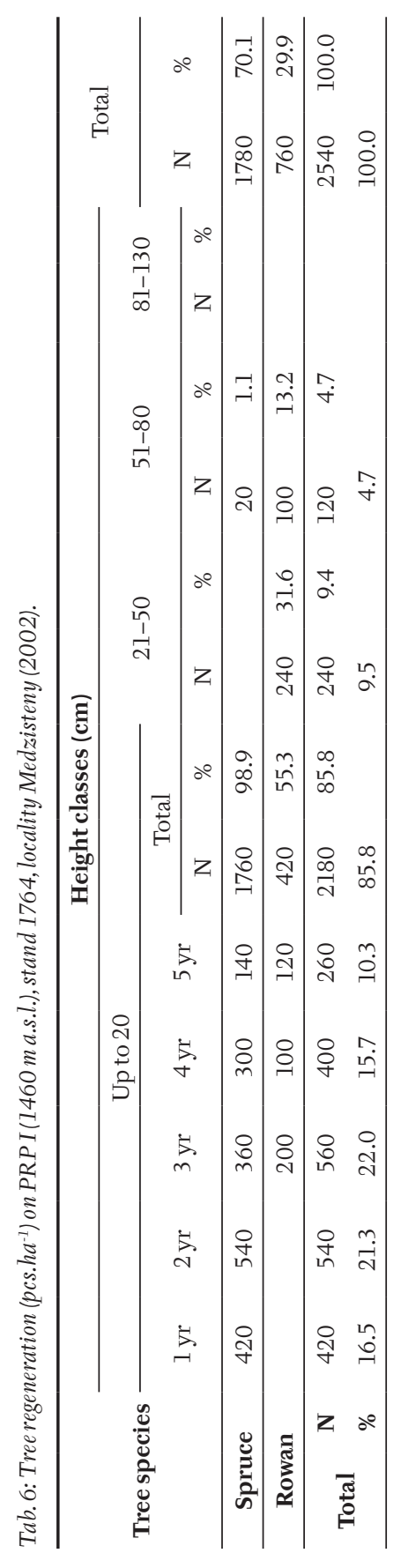


The stand volume recorded in this year on PRP IV is quite high regarding the state of the forest stand. Out of $736.3 \mathrm{~m}^{3} \cdot$ ha $^{-1}$ is only $144.5 \mathrm{~m}^{3}$ (19.6\%) in the living individuals (Tab. 4). This is unambiguously the result of the spontaneous - massive attack of bark-beetles. The reason is seen in the neglect of the forest hygiene - unprocessed calamity wood after the disturbance in 2004 in the neighbouring forest stands.

The fast decline process of forest ecosystems on the studied locality has negative effect on the regeneration process. Its speed is considerably slowed down or does not start at all.

Because of the security reasons, we did not register the biometric characteristics and natural regeneration in 2010 on PRP I and II. There were observed 104 pcs.ha $^{-1}$ of the spruce smaller than $20 \mathrm{~cm}$ on PRP III and 700 pcs.ha ${ }^{-1}$ on PRP IV. On PRP III there was not found any spruce higher than $20 \mathrm{~cm}$. In the calculation per hectare we registered 1,800 pieces of rowan and 200 pcs of sycamore maple. On PRP IV were discovered in the calculation per hectare 200 trees of spruce higher than $20 \mathrm{~cm}$ as well as 600 individuals of rowan and 300 of sycamore maple. The natural regeneration in both plots is considered to be insufficient. Due to the considerable decrease of the canopy cover without further regeneration it is possible to asses that on the plots the weeds will emerge, which would even slow down the process of natural regeneration.

\section{Conclusion and discussion}

Forest societies in the area of upper forest line have irreplaceable polyfunctionality. By its existence they fulfil ecological (soil-protection, anti-erosion, anti-avalanche, anti-landslide, water management) and environmental (health, relax, water protection, precipitation, aesthetic, educational, hinting, scientific) function. Wood production has secondary to tertiary importance (Midriak 1981, Stolina et al. 1985, Ammer, Probst 1991, Hladík et.al. 1993, Ott et al. 1995, Gubka 1996, 1998, Réh 1997, Saniga 2006, Saniga, Balanda 2008, Kucbel 2011, Pittner 2012).

In the time of research plots establishment (in 2002), the stand structure was very differentiated mostly due to the locality - different altitude. Parts of the stand in the lower altitude (PRP III and IV) had vertically nivelized structure. In the $1^{\text {st }}$ and $2^{\text {nd }}$ tree class that constitutes the canopy, there were $90-94 \%$ of the trees. The occurrence of living spruce individuals in the $4^{\text {th }}$ tree category was minimal or none on this plot. Horizontal canopy was in the range from 0.44 to 0.65 .
Different situation was discovered on PRP I (1,460 m), where $78.4 \%$ of individuals were in the $1^{\text {st }}$ and $2^{\text {nd }}$ tree class. In lower tree categories more than $20 \%$ of living spruces were discovered. Discovered horizontal canopy was 0.23 . The trees on this PRP were concentrated in the clusters and smaller groups (less than 0.2 hectare). This confirms the findings of various authors (Bialobok 1986. Gubka 2003, 2004, Hladík et.al. 1993 , Kucbel 2000, Kucbel et al. 2008, Korpel' 1989, Korpel', Saniga 1995, Mayer 1977, Mayer, Ott 1991, Ott et al.1995, Leibundgut 1982).

In the altitude 1,360 m (PRP II) in the time of research plots establishment was $22.6 \%$ of dead trees. More than $95 \%$ dead trees were in the $3^{\text {rd }}$ and $4^{\text {th }}$ tree class. This was probably caused by the ecological conditions and most probably by long lasting shading. The stand had the tendency to create biogroups of different size and density (numbers) in the higher altitudes.

With the decreasing altitude the diameter distribution is moving to the right which indicates the higher average values of stem diameter. This corresponds with the knowledge of Korpel' (1989), Gubka (1998), Kucbel (2003), Korpel', Saniga (1995).

The diameter distribution and vertical structure of the stand in the time of the research plots establishment was comparable with the advanced phase of the optimum stage (Korpel' 1989, Leibundgut 1982, Saniga 2006). In the time of repeated measurements, the situation on researched plots was considerably changed. Stands on PRP III and IV indicated the initial, or rather advanced phase of the decay stage. On PRP I and II there is visible a complete calamity decay caused by the wind disturbance.

The quality of tree crowns, crown ratio, slenderness ratio as well as a good anchoring of the root system showed relatively good static stability of the stand (Kodrík, Konôpka 1987, Jaloviar 2006). However, the stand was not able to resist the extremely strong wind in 2004. Static stability of the forest societies is possible to be influenced against the abiotic factors in the positive (as well as negative) sense only to some extent (Kodrík, Konôpka 1987, Novák, Slodičák 1999). It is possible to positively influence to a considerably high extent the health state of the forest, its biological and static structure, functional efficiency, production and biodiversity, and others through securing the high level of hygiene in forest stands (Stolina et al. 1985, Ott et al. 1995, Gubka 1996, 1998). The neglect (prevention of realization) of sanitary logging - health selection and unprocessed wood mass after the wind 
disturbance is the reason of massive outbreak of the pest, due to which the adult - functionally effective stands died and are still dying.

The natural regeneration of climax trees is minimal. On many places there is none. This supports the findings of Hančinský (1972) about the very weak natural regeneration in the forest type 7405 limestone maple-spruceforests. There is an assumption that leaving the research plots for the succession processes will take several decades. Without the conceptual combined, or rather artificial regeneration there could arrive spontaneous soil-destructive processes.

Polyfunctionality of forest ecosystems on this locality is considerably decreased. The neglect of forest hygiene and adequate silvicultural

\section{References}

Ammer, U., Probst, U. 1991: Freizeit und Natur. Verlag Paul Parey, Hamburg, 228 pp.

Bıацовок, S. 1986: Modrzewie larix Mill [European larch Mill]. Paňstwowe wydawnictwo naukowe, Poznaň: 411-425.

GuBKA, K. 1996: Štruktúra porastov hornej hranice lesa $\mathrm{v}$ závislosti na expozícii a nadmorskej výške [The timberline stand structure depending up to exposure and altitude]. Acta Facultatis Forestalis Zvolen 38: 115-125.

GuBKA, K. 1998: Štruktúra porastov pod hornou hranicou lesa na lokalite Jasienok [The timberline stand structure on locality Jasienok]. Acta Facultatis Forestalis Zvolen 40: 29-39.

GuBKA, K. 2003: Zmeny štruktúry porastu pod hornou hranicou lesa na LS Č́ierny Váh [Stand structure changes under the timberline on Čierny Váh]. Acta Facultatis Forestalis Zvolen 45: 151-160.

GuBKA, K. 2004: Súčasný stav porastov pod hornou hranicou lesa v Nízkych Tatrách na lokalite Lenivá (OLZ Beňuš) [Recent state of timberline stands in Nízke Tatry, locality Lenivá (Beňuš)]. Acta Facultatis Forestalis Zvolen 46: 131-143.

HANČINSKÝ, L. 1972: Lesnétypy Slovenska [Slovakian forest types]. Príroda, Bratislava, 307 s.

Hladík, M., Korpel, Š., LuKÁČ,T., Tesař,V. 1993: Hospodárenie v lesoch horských oblastí [Mountain zone forest management]. Lesnická fakulta VŠZ Praha a Matice lesnická Písek, $123 \mathrm{~s}$.

JALOVIAR, P. 2006: Vybrané morfologické parametre koreňov prirodzenej obnovy smreka na moderovom dreve a minerálnej pôde treatment leads to decline of stand condition and functionality in the upper tree line forests. Note: at present (year 2012) the entire studied and evaluated forest stand is due to the disturbance and extreme outbreak of barkbeetles, completely dead.

\section{Acknowledgement}

This contribution /publication is the result of the project implementation: Extension of the centre of Excellence „Adaptive Forest Ecosystems“, ITMS: 26220120049, supported by the Research \& Development Operational Programme funded by the ERDF.

v NPR Babia hora [Morfological parameter of Norway spruce regeneration roots on moder wood and mineral soil in NNR Babia hora]. Beskydy, 19: 125-130.

KodRÍr, J., KonôPKA, J. 1987: Mechanicképôsobenie vetra a snehu na lesné porasty [Wind and snow mechanical influence on forests]. Lesnícke informácie, Bratislava, 187 s.

KorPEL, S. 1989: Pralesy Slovenska [Slovak primeval forests]. Bratislava, Veda, $332 \mathrm{~s}$.

Korpel, Š. SANIGA, M. 1995: Prírode blízke pestovanie lesa [Close-nature silviculture]. Zvolen, UVVP LVH SR, $158 \mathrm{~s}$.

Kucbel, S. 2000: Štruktúra, zdravotný stav a regeneračné procesy $\mathrm{v}$ porastoch pod hornou hranicou lesa v Nízkych Tatrách [Structure, health and regeneration of stands under the treeline in Nízke Tatry Mts.]. Ochrana lesa a lesnícka fytopatológia 2000, TU Zvolen: 77-87.

Kucbel, S. 2003: Charakteristika modelovej štruktúry vysokohorského smrekového lesa v oblasti Prašivej v Nízkych Tatrách [Highelevation Norway spruce forest model structure in locality Prašivá, Nízke Tatry]. Acta facultatis forestalis Zvolen, 45: 173-186.

KucBeL, S., 2011: Štruktúra porastov a regeneračné procesy vo vysokohorských ochranných lesoch Nizkych Tatier [Stand structure and regeneration processes in high-elevation protection forests of Nízke Tatry Mts.]. Vedecká štúdia, TU Zvolen, 138 s.

Kucbel, S., Vencurik, J., 2008: Rolle der Vogelbeere (Sorbus aucuparia L.) in der Struktur eines Gebirgsfichtenwaldes. conference proceedings Die Rolle der Weichlaubbäume im Waldbau, Tharandt: 32-38. 
Kucbel, S., Vencurik, J., Jaloviar, P., Kuriš, P. 2008: Analýza štruktúry vo vysokohorskom ochrannom lese Nízkych Tatier [Stand structure analysis of high-elevation protection forests of Nízke Tatry Mts.]. Acta Facultatis Forestalis Zvolen, 50 (2): 57-65.

Leibundgut, H. 1982: Europäische Urwälder der Bergstufe. Verlag Paul Haupt Bern, 307 pp.

MAYER, H. 1977: Waldbau auf soziologisch-ökologischer Grundlage. Gustav Fischer Verlag, Stuttgart, $483 \mathrm{pp}$.

MAyeR, H., Отт, E. 1991: Gebirgswaldbau - Schutzwaldpflege, Gustav Fischer Verlag, Stuttgart, $587 \mathrm{pp}$.

MidRIAK, R. 1981: Diferencované obhospodarovanie lesa podl'a integrovaných funkcií [Different management of forests following integrated functions]. Lesnícke štúdie 31, VÚLH Zvolen, $224 \mathrm{~s}$.

NovĀK, J., SLodiČÁK, M. 1999: Zvyšování odolnosti smrkových porostů Jizerských hor vůči abiotickým škodlivým činitelům [Stability increas of Norway spruce stands against abiotical disturbances in locality Jizerské hory]. In: Obnova a stabilizace horských lesi̊, VULHM Opočno: 127-134.

Otт, E., Hladík, M., Korpel, Š., SAniga, M. 1995: Pestovanie horských lesov Švajčiarska a Slovenska [Switzerland and Slovakia mountain forest silviculture], ÚVVP LVH SR, Zvolen, 127 s.

Pittner, J. 2012: Analýza štrukturálnej diverzity ako kritéria pre hodnotenie ekologickej stability smrekového prírodného lesa v doline Nefcerka [Structural diversity analysis as a criterion for evaluation of ecological stability of Norway spruce natural forest in Nefcerka valley]. In: SANiga, M., Kucbel, S., Jaloviar, P (eds.): Pestovanie lesa v strednej Európe: 86-96.

Plesník, P. 1971: Horná hranica lesa vo Vysokých a Belianskych Tatrách [The timberline of $\mathrm{Vy}-$ soké and Belianske Tatry]. SAV Bratislava, $240 \mathrm{~s}$.

RéH, J. 1997: Pestovanie úćelových lesov [Special forests silviculture]. ES TU Zvolen, $218 \mathrm{~s}$.

SANIGA, M. 2006: Odvodenie modelu vysokohorského smrekového výberkového lesa v orografickom celku Oravské Beskydy [Model estimation of high-elevation Norway spruce selection forest in orography unit Oravské Beskydy]. Beskydy, 19: 137-142.

SAniga, M. 2007: Pestovanie lesa [Silviculture]. LF TU Zvolen, $247 \mathrm{~s}$.

Saniga, M. Balanda, M., 2008: Regeneračné procesy smrekového prírodného lesa v NPR Kosodrevina [Natural regeneration of the Norway spruce natural forest in the National
Nature Reserve Kosodrevina]. Beskydy, 21: 171-178.

ŠMeLKo, Š. 1991: Štatistickémetódy v lesníctve [Forestry Stastistical methods]. Skriptum, ES VŠLD Zvolen, $276 \mathrm{s.}$

Stolina, M. et al. 1985: Ochrana lesa [Forest protection]. Celostátní vysokoškolská učebnice. Príroda, Bratislava, 473 s. 